Arab World English Journal (AWEJ) Volume 12. Number2 June 2021

DOI: https://dx.doi.org/10.24093/awej/vol12no2.34

Pp. $496-520$

\title{
Saudi Female EFL Undergraduates' Knowledge, Perceptions, Problems, and Suggestions for Research Method Courses
}

\section{Talal Musaed Alghizzi}

Department of English Language and Literature, College of Languages and Translation, Imam Mohammad Ibn Saud Islamic University, Riyadh, Saudi Arabia

Email: Tmalghizzi@imamu.edu.sa

Received: 2/3/2021 Accepted: 6/23/2021 Published: 6/28/2021

\begin{abstract}
This study aimed to analyze English as a Foreign Language (EFL) students' knowledge and perceptions of research method courses in the Department of English Language and Literature, at Imam Mohammad Ibn Saud Islamic University (IMSIU). It also investigated the problems that students encounter and offered some suggestions for improving these courses. The significance of the study is that such topic has never been investigated before in such context. The study participants were 1,022 students (Levels three, four, five, six and seven) who voluntarily filled out a questionnaire consisting of sections on four factors/themes: knowledge, perceptions, problems, and suggestions. The collected data were analyzed using IBM SPSS Statistics software to compare the students' answers, and a one-way analysis of variance test was used to detect the differences between academic levels regarding each theme. The results showed that regardless of the students' academic levels, all of them agreed on studying and therefore knowing the research basic components; however, regarding the elements constituting each of these basic components, significant differences were found between the five groups. The results also indicated that these students have positive perceptions of the courses even though they encountered some researchrelated problems such as in knowing all or some research basic components and their specific elements; writing all or some of them; citing, summarizing, and paraphrasing sources; allocating primary and secondary resources; collecting and analyzing data; and consulting research manuals. Finally, all students agreed that it would be helpful if they were assigned individual research supervisors and coauthored an article with them, a research course was taught in all academic levels for a bachelor's degree, a research club was established, and research seminars were held.
\end{abstract}

Keywords: research methods, problems, suggestions, knowledge, perceptions, Saudi female EFL undergraduates

Cite as: Alghizzi, T. M. (2021). Saudi Female EFL Undergraduates' Knowledge, Perceptions, Problems, and Suggestions for Research Method Courses. Arab World English Journal, 12 (2) 496 -520. DOI: https://dx.doi.org/10.24093/awej/vol12no2.34 


\section{Introduction}

Saudi Arabia is well-known for being the world's biggest oil producer, and its efforts to support research and education are equally boundless. Such a great development is driven by a national educational strategy being employed through the 2030 Vision plan. During the few past years, the number of research publications in different science fields has increased (Fallatah, 2016). Al-Mutairi and Al-Shami (2015) stated that, "The research publication trend in Saudi Arabia for the past 25 years (1988-2013) was slow and lagging from 1988 until 2008 and had remarkable increase thereafter" (p. 85). King Salman bin Abdulaziz Al Saud firmly directed all sectors to activate their role in educational and scientific research to achieve the goal of transforming the kingdom into a knowledge-based country (Fallatah, 2016). Such an improvement would contribute to the development of social and economic prosperity. Undoubtedly, this shift is markedly reflected in the growth of different areas such as improved college programs and courses and the different kinds of learning.

Along this trend of development, Saudi universities implemented plans and programs to enhance scientific research methods by offering courses on advanced teaching methods (Fallatah, 2016). Hence, it is essential to assess the current research method courses to explore the deficient areas needing to be addressed. To achieve such a goal, this study intended to explore four factors/themes of research method courses: knowledge, perceptions, problems, and suggestions at IMSIU. In fact, to the researcher's knowledge, there is no research covering such an area, which aims to analyze learners' attitudes toward research method courses as an evaluation of their curricula. Thus, there is a knowledge gap on this specific point that can be fully resolved with learners' perceptions of research courses. This will help curriculum designers and linguistic researchers develop the research courses' quality and quantity and rethink learners' points of view in the future. Therefore, this research aimed to provide answers to the following questions:

1. Are there any significant differences between Level three, four, five, six, and seven female Saudi EFL undergraduates' research knowledge, perceptions, problems, and suggestions?

2. How knowledgeable are Level three, four, five, six, and seven female Saudi EFL undergraduates in terms of research basic components and the elements that constitute them?

3. What are Level three, four, five, six, and seven female Saudi EFL undergraduates' perceptions of research method courses?

4. What problems did Level three, four, five, six, and seven female Saudi EFL undergraduates encounter when studying in research method courses?

5. What suggestions did Level three, four, five, six, and seven female Saudi EFL undergraduates have for the betterment of research method courses?

\section{Literature Review}

\section{Students' Evaluating of College Courses}

Witte and Faigley (1983) declared that evaluating college courses is an extremely important step for forming a critical understanding of the existence of new courses, new methods, and new approaches. It is also a crucial step for transforming other courses to align with newly adopted resources. They maintained that the opinions of program evaluators, teachers, and learners constitute the necessity for course renewal. Zainal at el. (2012) confirmed 
that though there is no doubt the instructor is an important tool for delivering the course, considering other factors that can be effective for students' evaluations of a course also is important.

Curran and Rosen (2006) identified seven factors that constitute learners' satisfaction with a course. Many researchers have studied and analyzed these factors: (a) student effort (Church, Elliot, \& Gable, 2001; Ting, 2000), (b) student habits and practices, (c) student selfconfidence (Margolis \& McCabe, 2003), (d) the classroom environment (Church et al., 2001), (e) the technologies used in course delivery (Clarke, Flaherty, \& Mottner, 2001; Drago, Peltier, \& Sorensen, 2002), (f) student interactions with instructors and other students (Duffy, Warren, \& Walsh, 2001; Sander, Stevenson, King, \& Coates, 2000), (g) and workload (Kember \& Leung, 1998). Curran and Rosen (2006) confirmed, "These factors must be considered in any evaluation of courses" (p. 136).

Thus, identifying appropriate course evaluation factors/themes will inevitably provide insights for course developers and higher institutions to develop a better understanding of learners' needs and course requirements. In this study, students were asked to mark their preferable choices on a course's content, how it was, how it should be, and the difficulties they faced. Curran and Rosen (2006) stated that when evaluating a course, "Students must make choices with very little formal information as to what a course is about and how it will be conducted" (p. 136). Davis, Guiltinan, and Jones (1979) believed that course evaluators should depend on students' evaluations because they could provide different opinions that might positively enhance the course material.

\section{Improving Courses in the Department of English Language and Literature at IMSIU}

The College of Languages and Translation was established in 2001 to equip its students in the program of the Department of English Language and Literature with theoretical and practical knowledge of the language skills, linguistics, translation, and literature. Since then, there have been constant efforts to develop and improve the courses as they, in a great part, control the learning outcomes. Hence, one of the major objectives of the program is to improve students' individual, academic, and research abilities. Furthermore, the department has not ignored the role of assessing research method courses by surveying faculty members to evaluate the program's graduate students on their intellectual, personal, and professional skills and their ability to conduct research in different fields (Objectives of the Program, 2020). As such, this research was an attempt to consider the current college learners' knowledge, perceptions, problems, and suggestions for the purpose of improving the courses.

\section{Related Studies}

Studies dedicated to improving courses tend to evaluate the course curricula or the program courses related to a specific field (Hansen, 2014). Though many studies have tackled the issue of learners' perceptions of different academic courses, no study has scrutinized, to the best of the researcher's knowledge, EFL undergraduates' knowledge, attitudes, problems, or even suggestions for research method courses. For example, Lawson et al. (2002) submitted a report on student evaluations of five science and mathematics courses at Arizona State University. The authors employed workshops and teaching reforms supported by the American Association for the Advancement of Science. The results showed that teaching reforms improved student outcomes significantly. 
In another study, Curran and Rosen (2006) investigated learners' attitudes about four subject areas at a university in the northeastern United States using a model with seven factors. The findings revealed that factors associated with the physical environment, the course topic, the course execution, and the teacher's personality are powerful influences for learners to develop positive attitudes toward a course. Additionally, Hansen (2014) evaluated his teaching as well as the economic course he taught by creating an evaluation form as an assessment instrument. The form focused on what students learn. The analysis of the results reflected the strengths and weaknesses of the researcher's teaching method and provided insights about the course content, design, and pedagogy to enrich student learning.

\section{Method}

\section{Research Design}

Because of the significance and nature of this study in the sense that it required collecting data on various factors/themes related to research method courses from a large number of participants at a specific point in time, a combination of cross-sectional descriptive quantitative research designs was deemed to be the most suitable.

\section{Setting, Participants, and Research Method Courses}

This study was carried out one week before the final exam of the first semester of the academic year 2019-2020 in the Department of English Language and Literature of the College of Languages and Translation at IMSIU. The target population of participants was random students in the aforementioned department, from Level three to Level seven. The researcher chose Levels three through seven because students start studying research methods at the former level (Eng.233; see Appendix A for the course specification), and they apply their knowledge by writing a research proposal at the latter level (Eng.434; see Appendix B for the course specification). Levels four, five, and six were chosen to determine how much research knowledge students obtain before they reach Level seven, not to mention that the students are not allowed to register for Eng.434 unless they have successfully finished some of the requirements shown in Table one, which also illustrates the participants' distribution across the levels and the research courses' requirements.

Table 1. Participants' Academic Levels and Numbers and Research Course Requirements

Academic levels $\quad$ Number of participants Requirements

Listening and Speaking (Eng.102),

Level 3

Reading Comprehension (Eng.104),

Writing Skills (Eng. 112), and

English Grammar (Eng.119)

Level 4

Level 5

No requirements

Level 6

200

Level 7

177

Research Methods (Eng.233), and all Writing Skills courses (Eng.112, Eng.211, Eng.214, Eng.315, and Eng.316)

\section{Research Instruments}


Because of the scarcity of articles investigating EFL undergraduates' knowledge and problems in, perceptions of, and suggestions for the betterment of mandatory research courses in any context, the researcher designed a five-item Likert-scale questionnaire inquiring about the aforementioned elements. In other words, the questionnaire consisted of four sections, one each on knowledge, perceptions, problems, and suggestions. Each section included one general question on how much Saudi EFL undergraduates agree or disagree with one general statement followed by some specific element-related questions. The questionnaire was proofread by three professors of linguistics who had previously taught the course in the college. Their comments, corrections, and suggestions were taken into consideration. Then the questionnaire was transferred to Google Forms.

\section{Data Collection Procedures}

The Academic Advising Unit provided a list of all of the college's course instructors one week before the final exam. The female instructors of research method courses (Levels three and seven) were contacted to administer the questionnaire's electronic version to their students. The same procedure was undertaken for Level four, five, and six students; however, their instructors were told to inform their students that only those who took Eng.233 in Level three could participate in the study.

\section{Data Analysis}

The collected data were analyzed with IBM SPSS Statistics software to calculate statistics such as means and standard deviations. In addition, a one-way analysis of variance (ANOVA) test was used to detect the differences between academic levels regarding the four elements: knowledge, perceptions, problems, and suggestions.

\section{Results}

\section{Undergraduates' Knowledge of Research Basic Components}

Table two presents the results of female Saudi EFL undergraduates' knowledge of basic research components (see appendix C). The table shows descriptive statistics of all academic level participants' knowledge of research basic components. In the 14 items, the five groups were all slightly above the midpoint of the scale (3.40), indicating that all groups agreed that they have studied and know all the components mentioned. The following outcomes reveal the differences between the groups in terms of their academic levels:

- For Item one, the highest mean score was awarded to Level seven (4.4689), whereas Level six (4.1750) scored the lowest.

- For Item two, the highest mean score was awarded to Level seven (4.0339), whereas Level four (3.9007) scored the lowest.

- For Item three, the highest mean score was awarded to Level four (4.1029), whereas Level 3 (3.8629) scored the lowest.

- For Item four, the highest mean score was awarded to Level five (4.0121), whereas Level 3 (3.8145) scored the lowest.

- For Item five, the highest mean score was awarded to Level five (3.9677), whereas Level seven (3.7797) scored the lowest.

- For Item six, the highest mean score was awarded to Level five (3.9677), whereas Level seven (3.7910) scored the lowest. 
- For Item seven, the highest mean score was awarded to Level four (4.3640), whereas Level six (4.0750) scored the lowest.

- For Item eight, the highest mean score was awarded to Level seven (4.1469), whereas Level three (3.9355) scored the lowest.

- For Item nine, the highest mean score was awarded to Level seven (4.1525), whereas Level 3 (3.7903) scored the lowest.

- For Item 10, the highest mean score was awarded to Level four (4.1691), whereas Level 3 (3.8629) scored the lowest.

- For Item 11, the highest mean score was awarded to Level five (4.0887), whereas Level 6 (3.8200) scored the lowest.

- For Item 12, the highest mean score was awarded to Level five (4.1250), whereas Level 3 (3.9435) scored the lowest.

- For Item 13, the highest mean score was awarded to Level five (4.2429), whereas Level 3 (3.9194) scored the lowest.

- For Item 14, the highest mean score was awarded to Level five (4.0478), whereas Level 6 (3.8450) scored the lowest.

The ANOVA test results showed that the significance for Items one $(p=.006), 7(p=$ $.000)$, eight $(p=.008)$, nine $(p=.002), 10(p=.001)$, eleven $(p=.008), 12(p=.000)$, and $13(p$ $=.000)$ were below 0.05. Therefore, there were statistically significant differences between the academic levels for these items. For Items two, three, four, five, six, and 14, the significance was above 0.05 , meaning that there were no significant differences between the students' levels for these items.

\section{Undergraduates' Knowledge of Elements Constituting Research Basic Components}

Table three displays the results on female Saudi EFL undergraduates' knowledge of elements constituting each research basic component (see appendix D). The table indicates that the means for Level seven in the 12 items reflected their disagreement about neither studying nor knowing the elements constituting each research basic component, which revealed that students do not really remember these elements. In contrast, the means for Levels three, four, and five showed their agreement that they had studied all of the elements of the research basic components. However, Level six seemed undecided regarding remembering these elements. To generalize, it is obvious from Table three that the highest mean scores for Items one, two, three, four, five, six, 10, 11, and 12 were awarded for Level three, whereas Level four scored the highest on Items seven, eight, and nine. Level seven scored the lowest on all items. The ANOVA test results showed that the significance for all items was below 0.05 . Therefore, there were statistically significant differences between the academic levels for all of these items.

\section{Undergraduates' Perceptions of Research Method Courses}

Table four shows female Saudi EFL undergraduates' general perceptions of research method courses (see appendix E). The table reveals that all academic levels' means for the five items were slightly above the midpoint of the scale, indicating that the majority of students in all levels agreed positively that their research method course was beneficial, was a good foundation for scientific research, was important for understanding scientific research, was necessary to write a scientific research proposal, and should be mandatory in any bachelor's degree program. 
The ANOVA test results indicated that the significance for all items was above 0.05 . Therefore, there were no statistically significant differences between the academic levels for all of these items.

Table five presents female Saudi EFL undergraduates' perceptions of the research method course components (see appendix F). The table indicates that the nine items' means for all academic levels were slightly above the midpoint of the scale, showing that the majority of students $(M=4.2919-3.9628)$ agreed positively that the research method courses help students choose a research topic and identify research types and classifications, research designs and instruments for data collection, and the research problem. These courses also assist them with how to write the introduction, citations, research questions, and results and utilize the library and internet to write the literature review. The ANOVA test results revealed that the significance for some items was above $0.05(2=.055,6=.057,8=.092)$. Therefore, there were no statistically significant differences between the academic levels for all of these items. As for the other items $(1=.029,3=.001,4=.000,5=.022,7=.045,9=.001)$, the results showed that the significance for these items was less than 0.05 which means that there were statistically significant differences between the academic levels for all of these items.

\section{Undergraduates' Problems in Research Method Courses}

Table six displays the results regarding Saudi female EFL undergraduates' research problems (see appendix G). The table reveals that all academic levels' means for the six items were slightly above the midpoint of the scale, indicating that the majority of students $(M=$ 3.9442-3.7835) admitted encountering these difficulties. These problems include knowing all or some research basic components and their specific elements; writing all or some research basic components; citing, quoting, summarizing, and paraphrasing sources; allocating primary and secondary resources; collecting and analyzing data; and using research manuals to organize the research paper. Additionally, the ANOVA test results showed that the significance for Items one (.739), two (.305), three (.343), five (.436), and six (.146) was above 0.05 . Therefore, there were no statistically significant differences between the academic levels for these items. However, the significance for Item four was .038, which is less than 0.05 , indicating statistically significant differences between the academic levels for this item.

\section{Undergraduates' Suggestions for Research Method Courses}

Table seven shows the results regarding female Saudi EFL undergraduates' research suggestions (see appendix $\mathrm{H}$ ). The table indicates that the five items suggested to students for improving the research method courses. The academic levels' means in said items were all slightly above the midpoint of the scale, indicating that the majority of students $(M=4.1312-$ 3.9814) considered these suggestions valuable and significant. These suggestions included each student being assigned a research supervisor, students coauthoring articles with their research supervisors, a research course being taught at all academic levels, a research club being established, and research seminars being held. In addition, ANOVA test results showed that the significance for Items two (.076), three (.498), and four (.085) was above 0.05. Therefore, there were no statistically significant differences between the academic levels for these items. However, the significance for Items one (.004) and five (.048) was less than 0.05, indicating statistically significant differences between the academic levels for these items. 


\section{Discussion}

Based on the data shown above, the results show that all of the students across the various academic levels had acquired knowledge of research basic components. Although there are significant differences between all groups for some of the research basic components, the differences are still within the range of agreement that they know these components. Clarkson (2008) confirmed that in order for the long-term memories to become fixed and stored, they require learning and repetition, and they remain as such until they are retrieved by cues and triggers. Also according to Clarkson, it is easy for the brain to retrieve the basic components of knowledge, symbols, shapes, and colors, especially if the learned information is enhanced with practice and multiple exposures.

As for the specific elements that constitute each component of the research, significant differences were found between all groups. Levels three and four somehow agreed that they had acquired knowledge of these elements. In terms of the sixth level, students' knowledge remained neutral; the researcher cannot confirm or disconfirm their knowledge of these 12 elements. As for Level seven, the results showed disagreement about knowing the specific research elements. All of these results could mean that as students' progress from Level three to Level seven, their research knowledge deteriorates in terms of what constitutes the major elements of research. Students of all levels tend to remember all of the research basic components but gradually forget these components' specific elements as they progress through the academic levels. In other words, as students study the theoretical aspects of research methods in the third level and then continue to study the practical aspects of research in the seventh level, most of the students, according to this study, tend to forget the specific elements that constitute the research basic components.

Willingham (2015) confirmed that students go through learning loss over time if the learned knowledge is not activated. He tested students' knowledge twice to explore their retention of knowledge and found that the amount of time between the first and second tests is an important factor. For example, it is easier for students to remember the information they studied in high school when they are in their 20s rather than their 40s. Therefore, in this study, time is considered a crucial factor that bridges learners' knowledge of the theoretical aspects of research methods and the practical ones. That is to say, the less time that passes between the theoretical aspects and the practical aspects, the more improvement could be achieved in research knowledge. Ellis, Semb, and Cole (1998) investigated the effect of time on information retrieval. They administered several types of test to cognitive psychology students who graduated three to 125 months ago. Their results showed that the students' memory of concepts and important names was much better in the first three years after learning them but started to decline over the years.

Another factor that allows students to retrieve knowledge is repetitive exposure to the same information. Willingham (2015) stated, "We would also guess that the more a student originally learned in the course, the more she would remember" (p. 3). Hence, it is advised to assign two sequential semesters of research method courses for the purpose of repetitively exposing the students to the research basic components and research specific elements in a short time. 
Because the aim of this work was to improve research method courses further, the researcher explored learners' perceptions of these courses in general and of their components in particular. Initiating a study for the sake of improving a research course without a sound assessment of the learners' perceptions of the course is not considerably sufficient. The investigation of EFL learners' perceptions in this study evidences elevated scores regarding their interest in research courses. The results also show that the attributed usefulness of research method courses is captured by different components, such as confirming that the course is beneficial, is a good foundation for scientific research, is important for understanding scientific research, is necessary to write a scientific research proposal, and should be mandatory in any bachelor's degree program. Learners' satisfaction with these components reflected their importance in developing research skills, their interest in research courses, and their confidence. In their study, Secret, Ford, and Rompf (2003) found higher scores of interest in research courses among social work students. They investigated the relation between students' interest in research courses, their research orientation, and their research anxiety. The results of their students' attitudes toward research courses showed highly positive attitudes.

In this study, the analysis of research problems found that all students agree that the following constituted serious challenges for them: knowing all or some research basic components and their specific elements; writing all or some research basic components; citing, quoting, summarizing, and paraphrasing sources; allocating primary and secondary resources; collecting and analyzing data; and using research manuals to organize the research paper. A plausible explanation, though not the only one, for these problems can be attributed to students' low proficiency levels. Some students have low proficiency levels that are negatively reflected in the writing of their research projects. Cumming, Lai, and Cho (2016) declared that EFL students face different obstacles regarding the basic skills in the foreign language that may affect their research abilities.

Other possible reasons could include a lack of encouragement, a lack of experience in writing about research, a lack of motivation, and anxiety. Qasem and Zayid (2019) investigated the challenges that EFL learners at the University of Bisha face when they write proposals and research projects. The results revealed that EFL students encounter difficulties in choosing a topic and appropriate methodology, finding references, suffering a lack of interest in research, and guiding their research. Qasem and Zayid suggested motivating these students and equipping EFL learners with the best research strategies. In the same vein, Rungruangthum (2011) studied research problems of EFL university students. The data analysis of the semi-structured interviews revealed that anxiety stemming from academic failure is among the top reasons for these students' low performance in research writing.

Finally, in terms of the suggestions, the results of this study show no significant differences between the five groups as all of the participants agreed on the factors that would make the research courses more helpful: each of them being assigned a research supervisor other than the course teacher, coauthoring an article with the supervisor, the college implementing the courses at all academic levels, and the college establishing a research club and holding seminars and conferences. All of these results could mean that students realize the importance of the suggested items. To clarify, many studies (e.g., Alghizzi, 2011, 2012) have implicitly indicated that EFL students - regardless of the courses they are taking-study for final exam purposes 
only, and as soon as they finish, they tend to forget the memorized information. Exposing students to the same information with different techniques, environments, and means would most likely foster the feasibility of retrieving it when needed. Cowan (2008) asserted that memories that are frequently activated through exposure to the same information in different contexts can be recalled easily. He confirmed that such exposure would activate the neural networks in which the information is encoded, which will eventually activate the memory to remember the information easily.

\section{Conclusion, Implications, Limitations, and Recommendations}

This study was designed mainly for the purpose of examining four factors/themes: knowledge, perceptions, problems, and suggestions of female EFL undergraduates for the research method courses taught in the Department of English Language and Literature at the College of Languages and Translation. With such multifaceted results, there is a need to emphasize certain implications, limitations, and recommendations not only for the faculty of the above-mentioned college, but also for EFL researchers.

For example, the participants' results, though limited to being from one gender and having been extracted from a questionnaire, implied that the theoretical explanation of research components (basic and specific) — even with female students' highly positive research perception - is still not enough for the accurate and smooth execution of a research proposal. Students admitted encountering problems in the execution and application of the theoretical knowledge when choosing, collecting information on, writing about, and analyzing their research topics.

Replicating this research is recommended, but only with the inclusion of male EFL undergraduates and with semi-structured interviews. The prospective results would most likely substantiate the aforementioned ones and provide answers about why EFL undergraduates in general have or do not have positive perspectives on research courses and yet struggle or do not struggle to apply their knowledge.

What can be understood from this research in general and its results in particular is that the EFL undergraduates' completion of the prerequisite courses required for successful registration in the research method courses and the actual research writing practice-if there is any-are still insufficient.

The researcher could demand revision of the curricula for the bachelor's degree in English to include research courses from the first year, but such a suggestion is not feasible as the procedures to follow and the processes to go through to change a study plan require a long time and approval from the university-related deanships. Therefore, for immediate intervention, it is more practicable to modify the research method courses' specifications by increasing the courses' prerequisites and incorporating most - if not all — of the suggestions highlighted in this study. The researcher believes that making use of the time between the research method courses with the suggestions mentioned and allowing EFL undergraduates to write, revise, and edit their research topics repetitively and under the close guidance of individual supervisors would most likely enable the students to meet the research productivity they are expected to meet before 
graduation. Finally, it is recommended for EFL researchers to examine the above-mentioned success in order to expand its application in other similar colleges.

\section{About the Author:}

Talal Musaed Alghizzi, PhD. is an assistant professor in Applied Linguistics at Imam Mohammad Ibn Saud Islamic University (IMSIU). He has obtained his MA and PhD from University College Cork in Ireland. He is the chairman of the Chinese Department in the College of Languages and Translation. https://orcid.org/0000-0002-1088-9216

\section{References}

Alghizzi, T. M. (2011). The role of English writing instruction methodologies on the types of written mistakes/errors EFL graduate diploma students can identify in their writings, (Unpublished graduate diploma thesis). Dublin International Foundation College, Ireland.

Alghizzi, T. M. (2012). The role of English writing instruction methodologies on the types of written mistakes/errors Saudi EFL pre-university students can identify in their writings, (Unpublished Master's thesis). University College Cork, Ireland.

Al-Mutairi, K. A., \& Al-Shami, S. A. (2015). Scientific research in Saudi universities: Science thrives in the desert. Global Journal of Biology, Agriculture and Health Sciences, 4(3), 85-90.

Church, M. A., Elliot, A. J., \& Gable, S. L. (2001). Perceptions of classroom environment, achievement goals, and achievement outcomes. Journal of Educational Psychology, 93(1), 43-54. doi:10.1037//0022-0663.93.1.43

Clarke, I., III, Flaherty, T. B., \& Mottner, S. (2001). Student perceptions of educational technology tools. Journal of Marketing Education, 23(3), 169-177.

Clarkson, J. (2008). Human capability and product design. In H. N. J. Schifferstein, \& P. Hekkert (Eds.), Product experience (pp. 165-198). Amsterdam, Netherlands: Elsevier.

Cowan, N. (2008). What are the differences between long-term, short-term, and working memory? Progress in Brain Research, 169, 323-338. doi:10.1016/S00796123(07)00020-9

Cumming, A., Lai, C., \& Cho, H. (2016). Students' writing from sources for academic purposes: A synthesis of recent research. Journal of English for Academic purposes, 23, 47-58. doi.org/10.1016/j.jeap.2016.06.002

Curran, J. M., \& Rosen, D. E. (2006). Student attitudes toward college courses: An examination of influences and intentions. Journal of Marketing Education, 28(2), 135-148. doi:10.1177/0273475306288401

Davis, D. L., Guiltinan, J. P., \& Jones, W. H. (1979). Service characteristics, consumer search, and the classification of retail services. Journal of Retailing, 55(3), 3-23.

Drago, W., Peltier, J., \& Sorensen, D. (2002). Course content or the instructor: Which is more important in on-line teaching? Management Research News, 25(6/7), 69-83. doi.org/10.1108/01409170210783322

Duffy, J., Warren, K., \& Walsh, M. (2001). Classroom interactions: Gender of teacher, gender of student, and classroom subject. Sex Roles, 45(9-10), 579-593. doi.org/10.1023/A:1014892408105

Ellis, J. A., Semb, G. B., \& Cole, B. (1998). Very long-term memory for information taught in school. Contemporary Educational Psychology, 23(4), 419-433. doi.org/10.1006/ceps.1997.0976 
Fallatah, H. I. (2016). Introducing inter-professional education in curricula of Saudi health science schools: An educational projection of Saudi Vision 2030. Journal of Taibah University Medical Sciences, 11(6), 520-525. doi.org/10.1016/j.jtumed.2016.10.008

Hansen, W. L. (2014). Rethinking the student course evaluation: How a customized approach can improve teaching and learning. Liberal Education, 100(3). Available at https://www.aacu.org/publications-research/periodicals/rethinking-student-courseevaluation

Kember, D., \& Leung, D. Y. P. (1998). Influences upon students' perceptions of workload. Educational Psychology, 18(3), 293-307. doi:10.1080/0144341980180303

Lawson, A., et al., (2002). Evaluating college science and mathematics instruction: A reform effort that improves teaching skills. Journal of College Science Teaching, 31(6), 388393.

Margolis, H., \& McCabe, P. P. (2003). Self-efficacy: A key to improving the motivation of struggling learners. Preventing School Failure: Alternative Education for Children and Youth, 47(4), 162-169. doi:10.1080/10459880309603362

Objectives of the program. (2020). Imam Mohammad Ibn Saud Islamic University. Available at https://units.imamu.edu.sa/colleges/en/LanguageAndTranslation/profile/Pages/default.aspx

Qasem, F. A. A., \& Zayid, E. I. M. (2019). The challenges and problems faced by students in the early stage of writing research projects in L2, University of Bisha, Saudi Arabia. European Journal of Special Education Research, 4(1), 32-47. doi:10.5281/zenodo.2557036

Rungruangthum, M. (2011). Writing anxiety: EFL postgraduate students writing research papers in English. Journal of Studies in the English Language, 6, 185-198. Available at https://so04.tci-thaijo.org/index.php/jsel/article/view/21854/18846

Sander, P., Stevenson, K., King, M., \& Coates, D. (2000). University students' expectations of teaching. Studies in Higher Education, 25(3), 309-323. doi:10.1080/03075070050193433

Secret, M., Ford, J., \& Rompf, E. L. (2003). Undergraduate research courses: A closer look reveals complex social work student attitudes. Journal of Social Work Education, 39(3), 411-422. doi:10.1080/10437797.2003.10779146

Ting, K. F. (2000). Cross-level effects of class characteristics on students' perceptions of teaching quality. Journal of Educational Psychology, 92(4), 818-825. doi.org/10.1037/0022-0663.92.4.818

Witte, S. P., \& Faigley, L. (1983). Evaluating college writing programs. Carbondale and Edwardsville: Southern Illinois University Press.

Willingham, D. T. (2015). Do students remember what they learn in school? Ask the cognitive scientist. American Educator, 39(3), 33-38.

Zainal, N. F. A., Shahrani, S., Yatim, N. F. M., Rahman, R. A., Rahmat, M., \& Latih, R. (2012). Students' perception and motivation towards programming. Procedia-Social and Behavioral Sciences, 59, 277-286. doi: 10.1016/j.sbspro.2012.09.276 


\section{Appendices \\ Appendix A \\ Research Methods (Eng.233) Course Specification}

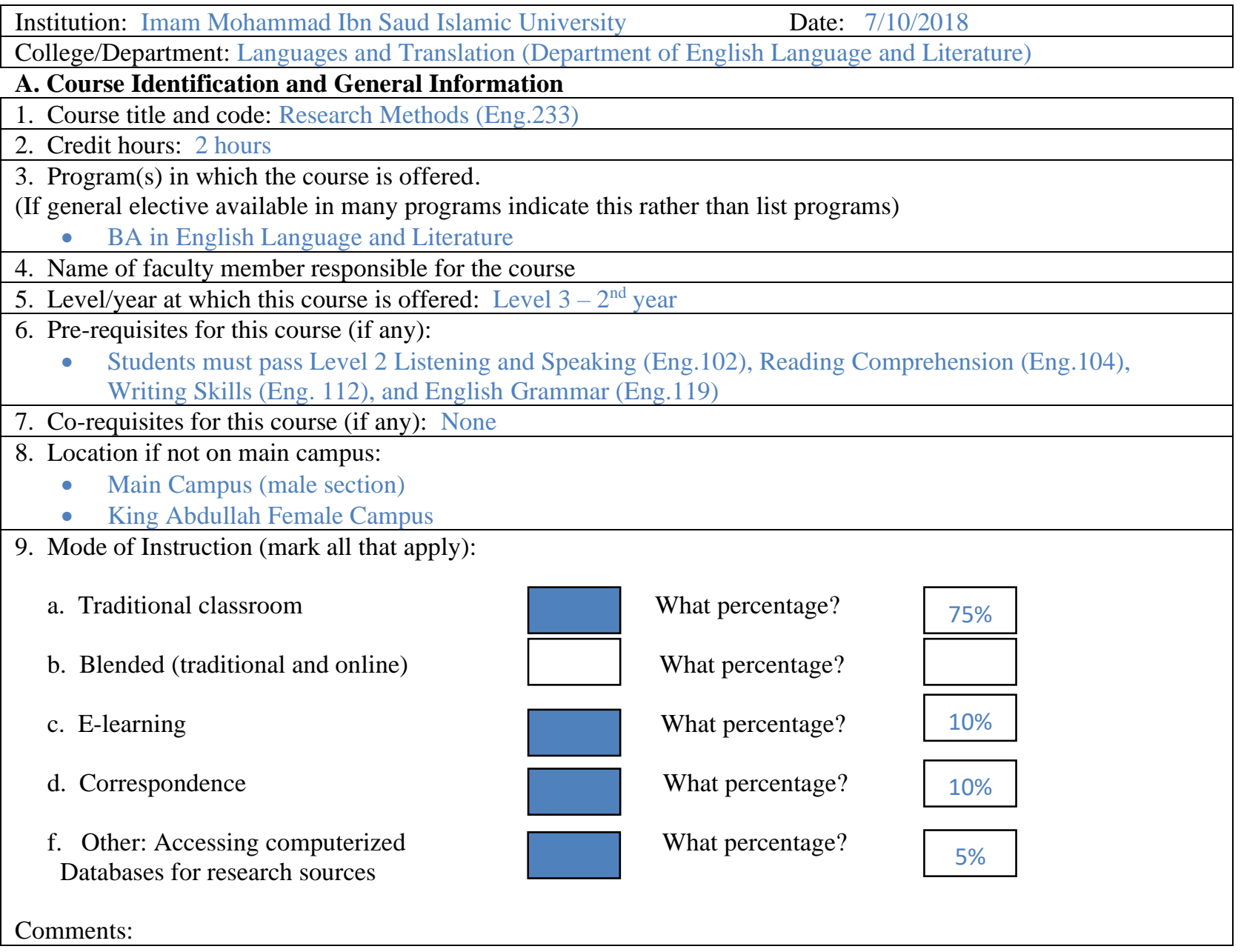

\section{B Objectives}

1. What is the main purpose for this course?

This course aims at familiarizing students with the basic issues and concepts in academic research.

2. Briefly describe any plans for developing and improving the course that are being implemented. (e.g. increased use of IT or web based reference material, changes in content as a result of new research in the field)

- Assigning students more active roles in the course by getting them to do an online search task based on every class.

- Updating the content of the course in light of recent research and recently published textbooks.

C. Course Description (Note: General description in the form used in Bulletin or handbook) Course Description:

The course introduces students to the main concepts in scientific research such as defining academic research and identifying its main steps, choosing a subject for a research paper, narrowing the subject into a research topic, writing a thesis statement, finding sources, evaluating reading sources, following the right academic reading strategies, how to cite references, and plagiarism. 
Arab World English Journal (AWEJ) Volume 12. Number 2. June 2021

Saudi Female EFL Undergraduates' Knowledge

Alghizzi

\begin{tabular}{|l|c|c|}
\hline 1. Topics to be Covered & $\begin{array}{l}\text { No. of } \\
\text { Weeks }\end{array}$ & Contact hours \\
\hline List of Topics & 1 & 2 \\
\hline Definition of a Research Paper & 1 & 2 \\
\hline Research Paper Sections, Chapters, and Organization & 1 & 2 \\
\hline Choosing and Narrowing a Research Topic & 1 & 2 \\
\hline Evaluating and Using Online Sources and Books & 1 & 2 \\
\hline Introduction & 1 & 2 \\
\hline Literature Review & 1 & 2 \\
\hline Methodology & 1 & 2 \\
\hline Results & 1 & 2 \\
\hline Discussion & 1 & 2 \\
\hline Conclusion & 1 & 2 \\
\hline References & 2 & 4 \\
\hline Citations, Quotations, and Plagiarism & 2 & \\
\hline Research Manuals (APA, MLA, etc.) & 1 & 2 \\
\hline Presentation of a research paper & $\mathbf{1 6}$ & $\mathbf{3 2}$ \\
\hline Total & & \\
\hline
\end{tabular}

\begin{tabular}{|c|c|c|c|c|c|c|c|}
\hline & & Lecture & Tutorial & $\begin{array}{c}\text { Laboratory/ } \\
\text { Studio }\end{array}$ & Practical & Other: & Total \\
\hline \multirow{2}{*}{$\begin{array}{l}\text { Contact } \\
\text { Hours }\end{array}$} & Planed & 24 & 8 & 0 & 0 & 0 & 32 \\
\hline & Actual & & & & & & \\
\hline \multirow{2}{*}{ Credit } & Planed & \multirow{2}{*}{\multicolumn{6}{|c|}{2}} \\
\hline & Actual & & & & & & \\
\hline
\end{tabular}

3. Additional private study/learning hours expected for students per week:

4. Course Learning Outcomes in NQF Domains of Learning and Alignment with Assessment Methods and Teaching Strategy

On the table below are the five NQF Learning Domains, numbered in the left column.

$\underline{\text { First, }}$, insert the suitable and measurable course learning outcomes required in the appropriate learning domains (see suggestions below the table). Second, insert supporting teaching strategies that fit and align with the assessment methods and intended learning outcomes. Third, insert appropriate assessment methods that accurately measure and evaluate the learning outcome. Each course learning outcomes, assessment method, and teaching strategy ought to reasonably fit and flow together as an integrated learning and teaching process. (Courses are not required to include learning outcomes from each domain.)

\begin{tabular}{|c|c|c|c|}
\hline $\begin{array}{c}\text { Code } \\
\#\end{array}$ & $\begin{array}{c}\text { NQF Learning Domains } \\
\text { And Course Learning Outcomes }\end{array}$ & $\begin{array}{c}\text { Course Teaching } \\
\text { Strategies }\end{array}$ & $\begin{array}{c}\text { Course Assessment } \\
\text { Methods }\end{array}$ \\
\hline 1.0 & \multicolumn{3}{|c|}{$\begin{array}{l}\text { Knowledge } \\
\text { By the end of this course, the TP student will be able: }\end{array}$} \\
\hline 1.1 & $\begin{array}{l}\text { List the good qualities for writing a } \\
\text { research paper }\end{array}$ & $\begin{array}{ll} & \text { Class discussion } \\
\text { - } & \text { Assignments } \\
\text { - } & \text { Case studies } \\
\end{array}$ & $\begin{array}{ll} & \text { Quiz } \\
\text { - } & \text { Presentations }\end{array}$ \\
\hline 1.2 & Write a proper thesis statement & $\begin{array}{l}\text { Group/pair work to } \\
\text { formulate tentative thesis } \\
\text { statements }\end{array}$ & $\begin{array}{l}\text { - Assignment } \\
\text { - Exam }\end{array}$ \\
\hline
\end{tabular}

Arab World English Journal

WWW.awej.org

ISSN: 2229-9327 
Arab World English Journal (AWEJ) Volume 12. Number 2. June 2021

Saudi Female EFL Undergraduates’ Knowledge

Alghizzi

\begin{tabular}{|c|c|c|c|}
\hline 1.3 & $\begin{array}{l}\text { Describe the different types of sources } \\
\text { (e.g. primary sources) }\end{array}$ & $\begin{array}{ll} & \text { Lecture } \\
\text { - } & \text { Introducing samples }\end{array}$ & $\begin{array}{ll} & \text { Exam } \\
\text { - } & \text { Presentations }\end{array}$ \\
\hline 2.0 & \multicolumn{3}{|c|}{$\begin{array}{l}\text { Cognitive Skills } \\
\text { By the end of this course, the TP student will be able: }\end{array}$} \\
\hline 2.1 & Compose the right research questions & $\begin{array}{ll}\text { - } & \text { Tutorial sessions } \\
\text { - } & \text { Assigned tasks } \\
\text { - } & \text { PowerPoint presentations } \\
\end{array}$ & - Exams and quizzes \\
\hline 2.2 & $\begin{array}{l}\text { Subdivide a model research paper into } \\
\text { its constituent sections (method, review } \\
\text { of literature, etc.) }\end{array}$ & $\begin{array}{ll}\text { - } & \text { Case studies } \\
\text { - } & \text { Class discussion } \\
\text { - } & \text { PowerPoint presentations }\end{array}$ & $\begin{array}{ll}\text { - } & \text { Assignments } \\
\text { - Reading an assigned } \\
\text { model article } \\
\text { - Quiz } \\
\end{array}$ \\
\hline 3.0 & \multicolumn{3}{|c|}{$\begin{array}{l}\text { Interpersonal Skills \& Responsibility } \\
\text { By the end of this course, the TP student will be able: }\end{array}$} \\
\hline 3.1 & $\begin{array}{l}\text { Illustrate one's thesis statement in a } \\
\text { research paper }\end{array}$ & $\begin{array}{l}\text { Group/pair work: } \\
\text { - } \quad \text { Presentations } \\
\text { - } \quad \text { Review analysis }\end{array}$ & $\begin{array}{l}\text { - } \quad \text { PowerPoint presentation } \\
\text { - Peer review }\end{array}$ \\
\hline 3.2 & $\begin{array}{l}\text { Demonstrate one's viewpoint avoiding } \\
\text { plagiarism (academic integrity) }\end{array}$ & - $\quad$ PowerPoint presentation & $\begin{array}{l}\text { - } \quad \text { Exam } \\
\text { Peer correction }\end{array}$ \\
\hline 4.0 & \multicolumn{3}{|c|}{$\begin{array}{l}\text { Communication, Information Technology, Numerical } \\
\text { By the end of this course, the TP student will be able: }\end{array}$} \\
\hline 4.1 & $\begin{array}{l}\text { Use electronic resources (data e.g. } \\
\text { bases) }\end{array}$ & $\begin{array}{l}\text { - Web search techniques } \\
\text { - Using Smart Boards }\end{array}$ & $\begin{array}{ll}\text { E-learning and online } \\
\text { assignments and projects } \\
\text { Electronic PowerPoint } \\
\text { presentations } \\
\end{array}$ \\
\hline 5.0 & \multicolumn{3}{|c|}{$\begin{array}{l}\text { Psychomotor } \\
\text { By the end of this course, the TP student will be able: }\end{array}$} \\
\hline 5.1 & $\mathrm{NA}$ & & \\
\hline 5.2 & NA & & \\
\hline
\end{tabular}

\begin{tabular}{|c|l|c|c|}
\hline \multicolumn{2}{|c|}{ 5. Schedule of Assessment Tasks for Students During the Semester } & $\begin{array}{c}\text { Proportion of Total } \\
\text { Assessment }\end{array}$ \\
\hline & $\begin{array}{c}\text { Assessment task (i.e., essay, test, quizzes, group project, } \\
\text { examination, speech, oral presentation, etc.) }\end{array}$ & Week Due & 10 \\
\hline 1 & Assigned homework tasks & All weeks & 5 \\
\hline 2 & Classroom short presentations & Week 12 & 10 \\
\hline 3 & Quizzes & Week 4 \& 7 & 15 \\
\hline 4 & Mid-term test & Week 8 & 60 \\
\hline 5 & Final-term exam & $\begin{array}{c}\text { End of the } \\
\text { term }\end{array}$ & \\
\hline 6 & & & \\
\hline
\end{tabular}

\section{Student Academic Counseling and Support}

1. Arrangements for availability of faculty and teaching staff for individual student consultations and academic advice. (include amount of time teaching staff are expected to be available each week)

Two hours a week will be allocated for individual student consultations and academic advice

\section{E Learning Resources}

1. List Required Textbooks

Rozakis, L. (2007) Schaum's Quick Guide to Writing Great Research Papers, 2 ${ }^{\text {nd }}$ ed., McGraw-Hill

2. List Essential References Materials (Journals, Reports, etc.)

Zemach, D. , Broudy, D. and Valvona, Ch. (2011). Writing Research Papers, Macmillan.

3. List Electronic Materials, Web Sites, Facebook, Twitter, etc.

https://www.msvu.ca/site/media/msvu/howtowrite.researchpaper2.pdf 
https://wac.colostate.edu/books/informedwriter/chapter10.pdf

http://dbis.rwth-aachen.de/ derntl/papers/misc/paperwriting.pdf

4. Other learning material such as computer-based programs/CD, professional standards or regulations and software.

None

\section{F. Facilities Required}

Indicate requirements for the course including size of classrooms and laboratories (i.e. number of seats in classrooms and laboratories, extent of computer access, etc.)

1. Accommodation (Classrooms, laboratories, demonstration rooms/labs, etc.)

$\checkmark$ A class computer

$\checkmark$ Data Show

$\checkmark \quad$ Smart Board equipped Classrooms

2. Technology resources (AV, data show, Smart Board, software, etc.)

$\checkmark$ Lecture rooms

$\checkmark$ Computer labs

3. Other resources (specify, e.g. if specific laboratory equipment is required, list requirements or attach list) None

G Course Evaluation and Improvement Processes

1. Strategies for Obtaining Student Feedback on Effectiveness of Teaching

Formal anonymous course evaluations by students at the end of course

In addition to informal student feedback throughout the semester

2. Other Strategies for Evaluation of Teaching by the Instructor or by the Department

In class, peer review to give support and disseminate good practice.

3. Processes for Improvement of Teaching

Discussing challenges in the classroom with colleagues.

4. Processes for Verifying Standards of Student Achievement (e.g. check marking by an independent member teaching staff of a sample of student work, periodic exchange and remarking of tests or a sample of assignments with staff at another institution)

Checking grading of a sample of examination papers either by a second faculty member marker

5. Describe the planning arrangements for periodically reviewing course effectiveness and planning for improvement.

Arranging with another institution to have two common test items included on an exam and compare marks given

Name of Course Instructor:

Signature:

Program Coordinator:

Date Specification Completed:

Signature:

Date Received:

\section{Appendix B}

Research (Eng.434) Course Specification

Institution: Imam Mohammad Ibn Saud Islamic University $\quad$ Date: 7/10/2018

A. Course Identification and General Information

1. Course title and code: Research (Eng.434)

2. Credit hours: 2 hours

3. Program(s) in which the course is offered.

(If general elective available in many programs indicate this rather than list programs)

- BA in English Language and Literature

4. Name of faculty member responsible for the course

5. Level/year at which this course is offered: Level $7-4^{\text {th }}$ year 
Arab World English Journal (AWEJ) Volume 12. Number 2. June 2021

Saudi Female EFL Undergraduates' Knowledge

Alghizzi

6. Pre-requisites for this course (if any):

- Students must pass Level 3 Research Methods (Eng.233) and all essay writing courses (Eng:112, 211, 214, $315, \& 316)$.

7. Co-requisites for this course (if any): None

8. Location if not on main campus:

- Main Campus (male section)

- King Abdullah Female Campus

9. Mode of Instruction (mark all that apply):

a. Traditional classroom

b. Blended (traditional and online)

c. E-learning

d. Correspondence

f. Workshops and activities

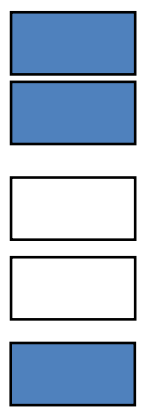

What percentage?

What percentage?

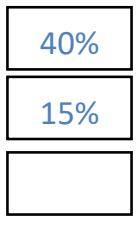

What percentage?

What percentage?

What percentage?

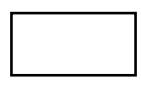

$45 \%$

Comments:

\section{B Objectives}

3. What is the main purpose for this course?

This course aims to allow level-seven students apply the research knowledge they gained from studying level-three Research Methods (Eng.233). Therefore, each student will write a research proposal which reflects their ability to: choose a research topic suiting a research paper that examines a specific researchable problem, locate relevant literature on the topic and write a literature review accordingly, form research questions/hypotheses skillfully, identify and design a particular methodological approach appropriate to their chosen research topic (e.g., selecting the participants and tools needed to gather data on the topic, etc.), critically synthesize data from quantitative and qualitative analyses, and document the cited references. All of such will be developed by students gradually by supplying multiple research drafts and presenting them.

4. Briefly describe any plans for developing and improving the course that are being implemented. (e.g. increased use of IT or web based reference material, changes in content as a result of new research in the field)

1. Increased use of IT or web-based reference material

2. Use Web-CT for uploading material

3. Consistently change the list of readings to include recent publications

4. Use of www.tesol.org and www.moodle.com for collaborative activities

5. Include e-books

C. Course Description (Note: General description in the form used in Bulletin or handbook) Course Description:

The course allows students to practically show the basic research processes and elements they learned from levelthree Research Method (Eng.233). It is particularly designed to develop students' research skills required for planning and executing basic research paper, help them explain in depth the main parts of the academic term paper, and train them on how to use the library, modern technology, and references and documentation, etc.

\section{Topics to be Covered}

\section{List of Topics}

Writing a Research Proposal: The three concepts

General Reading and Topic Selection 
Arab World English Journal (AWEJ) Volume 12. Number 2. June 2021

Saudi Female EFL Undergraduates’ Knowledge

Alghizzi

\begin{tabular}{|l|c|c|}
\hline Research Classification & 1 & 2 \\
\hline Writing the Introduction & 2 & 4 \\
\hline Research problems and Outline & 2 & 4 \\
\hline Library and the Internet and How to Utilize Them & 1 & 2 \\
\hline Review of Literature & 2 & 4 \\
\hline Research Design and Method & 2 & 4 \\
\hline Reviewing Documentation Style & 1 & 2 \\
\hline Referencing & 1 & 2 \\
\hline Oral Defense: Supervisor + External Examiner & 1 & 2 \\
\hline Total & $\mathbf{1 6}$ & $\mathbf{3 2}$ \\
\hline
\end{tabular}

\section{Course components (total contact hours and credits per semester):}

\begin{tabular}{|l|c|c|c|c|c|c|c|}
\hline \multicolumn{2}{|c|}{} & Lecture & Tutorial & $\begin{array}{c}\text { Laboratory/ } \\
\text { Studio }\end{array}$ & Practical & Other: & Total \\
\hline \multirow{2}{*}{$\begin{array}{l}\text { Contact } \\
\text { Hours }\end{array}$} & Planed & 20 & 10 & 0 & 0 & 0 & 30 \\
\cline { 2 - 8 } Credit & Actual & 20 & 10 & & & & 30 \\
\cline { 1 - 7 } & Planed & Actual & \multicolumn{2}{|c|}{2} & \\
\hline
\end{tabular}

\section{Additional private study/learning hours expected for students per week:}

4. Course Learning Outcomes in NQF Domains of Learning and Alignment with Assessment Methods and Teaching Strategy

On the table below are the five NQF Learning Domains, numbered in the left column.

First, insert the suitable and measurable course learning outcomes required in the appropriate learning domains (see suggestions below the table). Second, insert supporting teaching strategies that fit and align with the assessment methods and intended learning outcomes. Third, insert appropriate assessment methods that accurately measure and evaluate the learning outcome. Each course learning outcomes, assessment method, and teaching strategy ought to reasonably fit and flow together as an integrated learning and teaching process. (Courses are not required to include learning outcomes from each domain.)

\begin{tabular}{|c|c|c|c|}
\hline $\begin{array}{l}\text { Code } \\
\#\end{array}$ & $\begin{array}{l}\text { NQF Learning Domains } \\
\text { And Course Learning Outcomes }\end{array}$ & $\begin{array}{l}\text { Course Teaching } \\
\text { Strategies }\end{array}$ & $\begin{array}{l}\text { Course Assessment } \\
\text { Methods }\end{array}$ \\
\hline 1.0 & \multicolumn{3}{|c|}{$\begin{array}{l}\text { Knowledge } \\
\text { By the end of this course, the TP student will be able: }\end{array}$} \\
\hline 1.1 & $\begin{array}{l}\text { Outline the components of research } \\
\text { proposal }\end{array}$ & $\begin{array}{l}\text { - } \quad \text { Lectures } \\
\text { Class discussion }\end{array}$ & $\begin{array}{l}\text { Class participation } \\
\text { Written } \\
\text { assignments } \\
\end{array}$ \\
\hline 1.2 & Describe various kinds of references & $\begin{array}{l}\text { - } \quad \text { Lectures } \\
\text { Group discussion }\end{array}$ & $\begin{array}{l}\text { Quizzes and midterms } \\
\text { questions }\end{array}$ \\
\hline 2.0 & \multicolumn{3}{|c|}{$\begin{array}{l}\text { Cognitive Skills } \\
\text { By the end of this course, the TP student will be able: }\end{array}$} \\
\hline 2.1 & $\begin{array}{l}\text { Interpret and criticize the research that } \\
\text { others produce }\end{array}$ & $\begin{array}{l}\text { - Assigned texts for reading } \\
\text { Assigned texts for written } \\
\text { analysis }\end{array}$ & $\begin{array}{l}\text { Written assignments } \\
\text { Formal debates }\end{array}$ \\
\hline 2.2 & $\begin{array}{l}\text { Design and conduct simple research } \\
\text { studies under supervision }\end{array}$ & $\begin{array}{l}\text { A typed double-spaced } \\
\text { research essay } \\
\text { Assignments for } \\
\text { individual and group }\end{array}$ & $\begin{array}{l}\text { Individual/group } \\
\text { presentations }\end{array}$ \\
\hline
\end{tabular}


Arab World English Journal (AWEJ) Volume 12. Number 2. June 2021

Saudi Female EFL Undergraduates’ Knowledge

Alghizzi

\begin{tabular}{|c|c|c|c|}
\hline & & $\begin{array}{l}\text { presentations of a certain } \\
\text { topic pertaining to } \\
\text { research }\end{array}$ & \\
\hline 3.0 & \multicolumn{3}{|c|}{$\begin{array}{l}\text { Interpersonal Skills \& Responsibility } \\
\text { By the end of this course, the TP student will be able: }\end{array}$} \\
\hline 3.1 & Use the necessary skills to communicate & $\begin{array}{l}\text { Give students choices in } \\
\text { selecting their topics } \\
\text { Require a timeline and } \\
\text { evidence of work } \\
\text { completed for projects }\end{array}$ & $\begin{array}{l}\text { Show and explain } \\
\text { requirements and criteria } \\
\text { to students before } \\
\text { assignments so they } \\
\text { know what qualities are } \\
\text { desirable to be } \\
\text { demonstrated } \\
\end{array}$ \\
\hline 3.2 & $\begin{array}{l}\text { Show effective participation in class } \\
\text { discussion }\end{array}$ & $\begin{array}{l}\text { Assign group } \\
\text { projects/presentations } \\
\text { Include class participation } \\
\text { as a component of the } \\
\text { course assessment }\end{array}$ & $\begin{array}{l}\text { Give feedback on group } \\
\text { process along with } \\
\text { feedback on content }\end{array}$ \\
\hline 4.0 & \multicolumn{3}{|c|}{$\begin{array}{l}\text { Communication, Information Technology, Numerical } \\
\text { By the end of this course, the TP student will be able: }\end{array}$} \\
\hline 4.1 & $\begin{array}{l}\text { Demonstrate reputable websites for } \\
\text { research }\end{array}$ & $\begin{array}{l}\text { Initial assessment of IT } \\
\text { skill }\end{array}$ & $\begin{array}{l}\text { Typed written } \\
\text { assignments, written, and } \\
\text { oral exams }\end{array}$ \\
\hline 4.2 & $\begin{array}{l}\text { Assess the use of PowerPoint to support } \\
\text { a presentation }\end{array}$ & $\begin{array}{l}\text { - Include use of PowerPoint } \\
\text { as a necessary component } \\
\text { of a presentation }\end{array}$ & $\begin{array}{l}\text { Presentations and oral } \\
\text { exam }\end{array}$ \\
\hline 5.0 & \multicolumn{3}{|c|}{$\begin{array}{l}\text { Psychomotor } \\
\text { By the end of this course, the TP student will be able: }\end{array}$} \\
\hline 5.1 & $\mathrm{NA}$ & & \\
\hline 5.2 & $\mathrm{NA}$ & & \\
\hline
\end{tabular}

\begin{tabular}{|c|l|c|c|}
\hline 5. Schedule of Assessment Tasks for Students During the Semester \\
\hline \multicolumn{1}{|c|}{$\begin{array}{c}\text { Assessment task (i.e., essay, test, quizzes, group project, } \\
\text { examination, speech, oral presentation, etc.) }\end{array}$} & Week Due & $\begin{array}{c}\text { Proportion of Total } \\
\text { Assessment }\end{array}$ \\
\hline 1 & Midterm & Week 8 & 20 \\
\hline 2 & Midterm & Week 13 & 20 \\
\hline 3 & Research proposal: final draft & Week 15 & 50 \\
\hline 4 & Oral exam (defense of the paper presented) & Week 16 & 10 \\
\hline
\end{tabular}

D. Student Academic Counseling and Support

1. Arrangements for availability of faculty and teaching staff for individual student consultations and academic advice. (include amount of time teaching staff are expected to be available each week)

Three office hours per week

\section{E Learning Resources}

1.List Required Textbooks

Lecture Notes

The Essential Guide to Doing Your Research Project 2ndEdition(2013),by Zina O'Leary (Author).

2. List Essential References Materials (Journals, Reports, etc.)

Burns, A. (2009). Doing Action Research in English Language Teaching. (eBook).

Ellis, B. (1989). How to Write Themes and Term Papers. 3rd Edition. New York: Barron's Educational Series.

Greswell, J. (1994). Research Design :Qualitative and Quantitative Approaches. Thousand Oak: Sage.

Lester, J. (1996). Writing Research Papers: A Complete Guide. 8th ed. NY: Harper Collins. MLA Handbook for

Writers of Research Papers. (2009). 7th ed. NY:MLA.

Publication Manual of the APA. (2010). 6th ed. Washington, DC:APA.

Rozakis, L. (2007). Schaum's Quick Guide to Writing Great Research Papers. 2nd ed. NY: McGraw-Hill. 


\section{Saudi Female EFL Undergraduates' Knowledge Alghizzi}

3. List Electronic Materials, Web Sites, Facebook, Twitter, etc.

http://.1lt.msu.edu

http://.tesol-journal.com

http://eltj.oxfordjournals.org

4. Other learning material such as computer-based programs/CD, professional standards or regulations and software.

Signed Student Code of honor explained during student orientation to university to protect against plagiarism

The use of http://turnitin.com software program to detect plagiarism

\section{F. Facilities Required}

Indicate requirements for the course including size of classrooms and laboratories (i.e. number of seats in classrooms and laboratories, extent of computer access, etc.)

1. Accommodation (Classrooms, laboratories, demonstration rooms/labs, etc.)

$\checkmark \quad$ Lecture rooms should be large enough to accommodate 70 students

2. Technology resources (AV, data show, Smart Board, software, etc.)

$\checkmark \quad$ Laptop computer - projector system

3. Other resources (specify, e.g. if specific laboratory equipment is required, list requirements or attach list)

$\checkmark \quad$ Data show to facilitate going over student papers in class

G Course Evaluation and Improvement Processes

1. Strategies for Obtaining Student Feedback on Effectiveness of Teaching

- Midterm evaluation feed-back form to increase instructor's awareness of the weak and strong points of the class

- End of term college evaluation of course by students (to be collected by the department)

- End-of-term debriefing in class of students and teacher regarding what went well and what could have gone better

- Small group instructional diagnosis (SGID) whereby instructors exchange classes and gather information from each other's students on specific points outlined by the department and the instructor being evaluated

2. Other Strategies for Evaluation of Teaching by the Instructor or by the Department

1. Self-evaluation

2. Prepare general file for course

3. Review sample of students' work by another staff member

4. Evaluation of a sample exam and drill by another staff member

5. Peer evaluation to assess ability of faculty members to work with their colleagues

3. Processes for Improvement of Teaching

1. Training sessions

2. Workshops to facilitate the exchange of experiences amongst faculty members

3. Regular meetings where problems are discussed and solutions given

4. Discussion of challenges in the classroom with colleagues and supervisors

5. Encouragement oSf faculty members to attend professional development conferences

6. Keep up to date with pedagogical theory and practice

7. Set goals for achieving excellence in teaching at the beginning of each new semester after reviewing last semester's teaching strategies and results

4. Processes for Verifying Standards of Student Achievement (e.g. check marking by an independent member teaching staff of a sample of student work, periodic exchange and remarking of tests or a sample of assignments with staff at another institution)

1. Identify rubrics for each students' activity or assignment

2. Check marking of a sample of examination papers either by a resident or visiting faculty member

3. Arrange with another institution to have two common test items included on an exam and compare marks given

4. Students who believe they are under graded can have their papers checked by a second reader

5. Describe the planning arrangements for periodically reviewing course effectiveness and planning for improvement.

Name of Course Instructor: 
Arab World English Journal (AWEJ) Volume 12. Number 2. June 2021

Saudi Female EFL Undergraduates’ Knowledge

Alghizzi

Signature: Date Specification Completed:

Program Coordinator:

Signature:

Date Received:

\section{Appendix C}

Table 2. Female Saudi EFL undergraduates' knowledge of research basic components

To what extent do you agree or disagree with the following statements?
I have studied and therefore know these research basic components in the course:

Research basic components

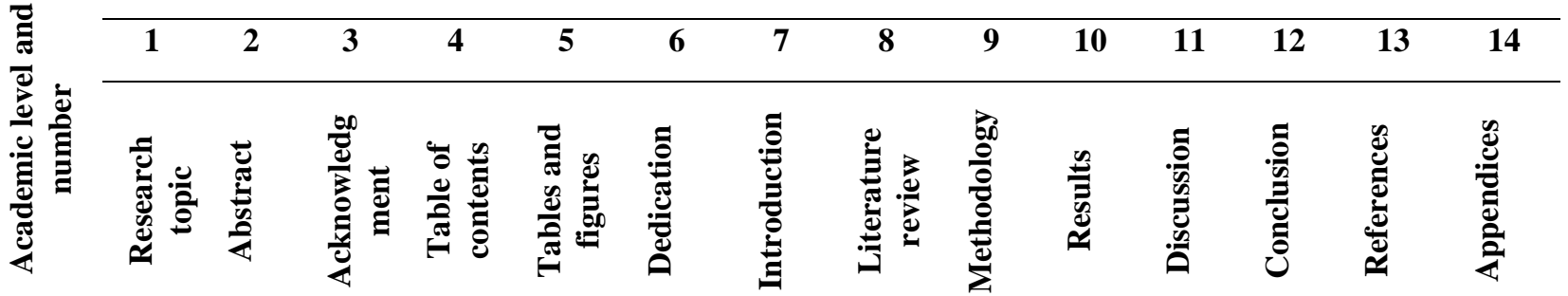

\begin{tabular}{|c|c|c|c|c|c|c|c|c|c|c|c|c|c|c|c|}
\hline & $\boldsymbol{M}$ & 4.29 & 3.97 & 3.86 & 3.814 & 3.838 & 3.830 & 4.19 & 3.935 & 3.79 & 3.86 & 4.00 & 3.94 & 3.919 & 3.967 \\
\hline$\forall$ & & 84 & 58 & 29 & 5 & 7 & 6 & 35 & 5 & 03 & 29 & 00 & 35 & 4 & 7 \\
\hline & & .662 & .821 & 913 & 1.023 & .9490 & .925 & .833 & 9689 & .965 & .948 & .855 & .956 & .8980 & .9364 \\
\hline & $\mathrm{S}$ & 34 & 10 & 62 & 04 & 0 & 9 & 03 & 7 & 03 & 55 & 40 & 81 & 3 & 8 \\
\hline
\end{tabular}

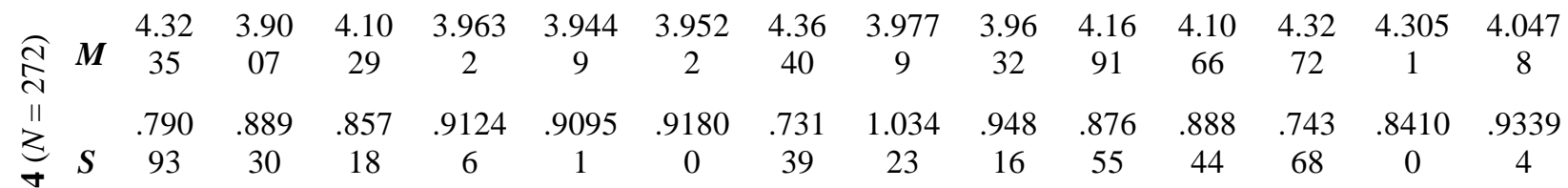

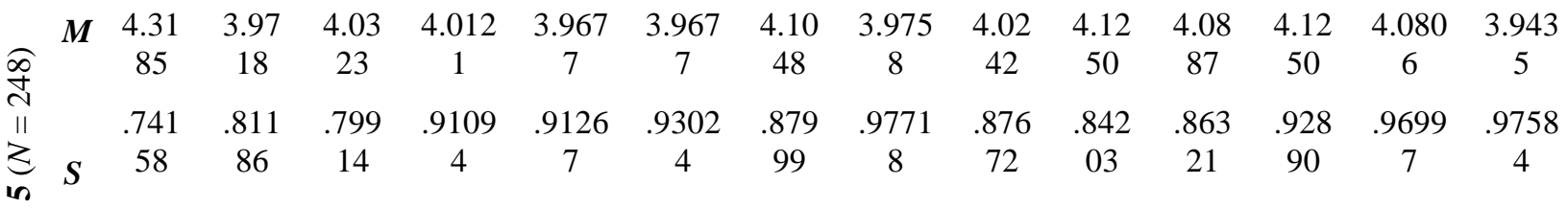

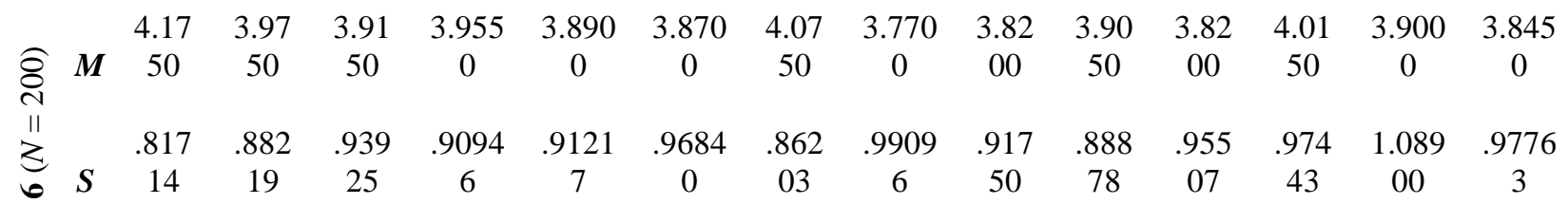

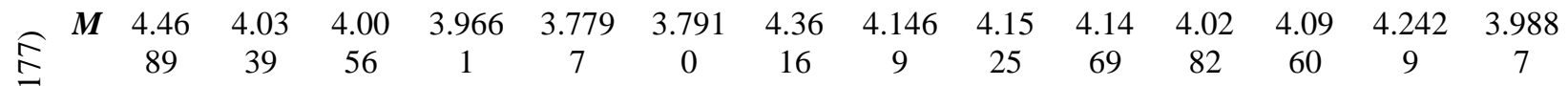

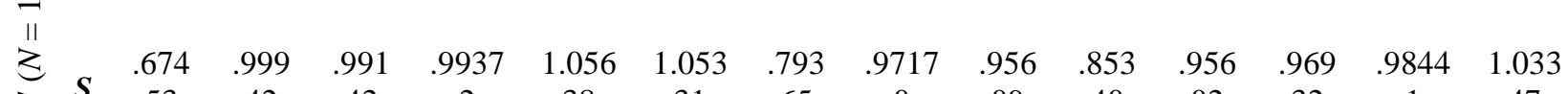

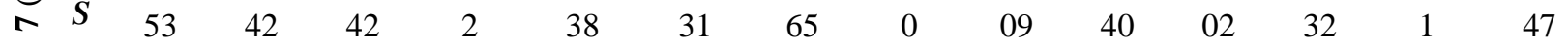

$\begin{array}{llllllllllllll}4.31 & 3.96 & 4.00 & 3.955 & 3.898 & 3.897 & 4.22 & 3.960 & 3.96 & 4.06 & 4.01 & 4.13 & 4.113 & 3.962\end{array}$

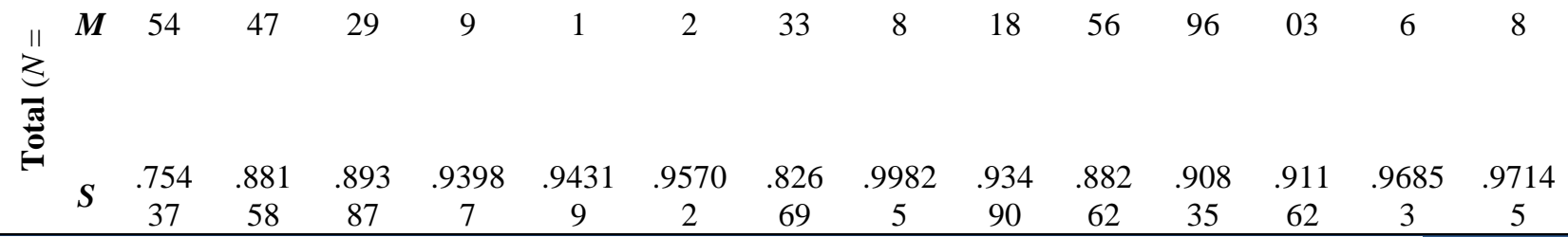

Arab World English Journal

www.awej.org

516

ISSN: 2229-9327 
Arab World English Journal (AWEJ) Volume 12. Number 2. June 2021

Saudi Female EFL Undergraduates’ Knowledge

Alghizzi

\begin{tabular}{|c|c|c|c|c|c|c|c|c|c|c|c|c|c|c|}
\hline \multicolumn{15}{|c|}{ ANOVA results } \\
\hline $\boldsymbol{E}$ & 3.62 & .645 & 2.17 & .932 & 1.331 & 1.299 & 6.25 & 3.451 & 4.36 & 4.95 & 3.44 & 5.43 & 7.379 & 1.314 \\
\hline$F$ & 6 & & 3 & & & & 6 & & 8 & 8 & 8 & 1 & & \\
\hline Sig. & $\begin{array}{c}.006 \\
*\end{array}$ & .630 & .070 & .444 & .256 & .269 & $\begin{array}{c}.000 \\
*\end{array}$ & $.008 *$ & $\begin{array}{c}.002 \\
*\end{array}$ & $\begin{array}{c}.001 \\
*\end{array}$ & $\begin{array}{c}.008 \\
*\end{array}$ & $\begin{array}{c}.000 \\
*\end{array}$ & $.000 *$ & .263 \\
\hline
\end{tabular}

Note. $(*)$ indicates the significant results at 0.05

\section{Appendix D}

Table 3. Female Saudi EFL undergraduates' knowledge of elements constituting each research basic component

To what extent do you agree or disagree with the following statements?

I have studied and therefore know the elements constituting the following research basic components:

\begin{tabular}{|c|c|c|c|c|c|c|c|c|c|c|c|c|c|}
\hline \multirow{2}{*}{\multicolumn{2}{|c|}{ 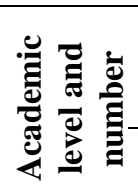 }} & \multicolumn{12}{|c|}{ Research basic components } \\
\hline & & 1 & 2 & 3 & 4 & 5 & 6 & 7 & 8 & 9 & 10 & 11 & 12 \\
\hline \multirow{3}{*}{$\frac{\underset{\mathrm{J}}{\mathrm{J}}}{\|}$} & \multirow{3}{*}{$\boldsymbol{M}$} & 4.35 & 4.12 & 3.90 & 3.84 & 3.90 & 3.84 & 3.86 & 3.95 & 3.86 & 4.08 & 4.04 & 3.95 \\
\hline & & 48 & 10 & 32 & 68 & 32 & 68 & 29 & 97 & 29 & 87 & 84 & 97 \\
\hline & & .734 & .861 & .914 & .996 & .966 & .919 & 1.06 & .931 & 1.06 & .919 & .834 & .957 \\
\hline$\underset{m}{\vdots}$ & $S$ & 66 & 01 & 38 & 29 & 25 & 92 & 179 & 82 & 179 & 63 & 76 & 63 \\
\hline \multirow{3}{*}{$\underset{I}{\stackrel{\overbrace{}}{N}}$} & \multirow{3}{*}{$\boldsymbol{M}$} & 4.14 & 3.95 & 3.77 & 3.73 & 3.86 & 3.76 & 3.97 & 4.01 & 4.00 & 3.98 & 3.90 & 3.91 \\
\hline & & 34 & 22 & 21 & 90 & 40 & 47 & 79 & 84 & 37 & 53 & 44 & 54 \\
\hline & & .887 & .929 & .932 & 1.01 & 1.00 & .973 & .952 & .981 & .992 & 1.02 & 1.09 & .950 \\
\hline$\vdots$ & $S$ & 40 & 98 & 93 & 732 & 178 & 72 & 50 & 20 & 59 & 360 & 260 & 93 \\
\hline \multirow{3}{*}{$\underset{\|}{\stackrel{\infty}{ \pm}}$} & \multirow{3}{*}{$\boldsymbol{M}$} & 4.00 & 3.79 & 3.78 & 3.62 & 3.64 & 3.76 & 3.79 & 3.78 & 3.77 & 3.72 & 3.73 & 3.84 \\
\hline & & 00 & 44 & 23 & 10 & 52 & 21 & 84 & 23 & 02 & 98 & 79 & 68 \\
\hline & & .989 & .986 & .998 & .994 & .953 & 1.01 & .993 & .986 & .981 & .962 & 1.00 & .994 \\
\hline \multirow{2}{*}{$\underset{1 n}{\geqq}$} & $S$ & 83 & 78 & 46 & 66 & 95 & 997 & 74 & 22 & 40 & 66 & 598 & 27 \\
\hline & & 2.86 & 2.78 & 2.75 & 2.78 & 2.75 & 2.72 & 2.80 & 2.84 & 2.81 & 2.87 & 2.82 & 2.77 \\
\hline \multirow{3}{*}{$\begin{array}{l}\widehat{\Xi} \\
\stackrel{1}{ } \\
11 \\
\vdots \\
0\end{array}$} & $M$ & 00 & 00 & 50 & 00 & 50 & 50 & 50 & 00 & 50 & 00 & 00 & 00 \\
\hline & & .874 & .737 & .698 & .602 & .661 & .649 & .706 & .817 & .730 & .738 & .707 & .655 \\
\hline & $S$ & 20 & 78 & 15 & 84 & 18 & 22 & 73 & 15 & 37 & 80 & 18 & 17 \\
\hline \multirow{5}{*}{ 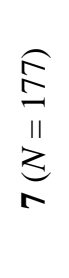 } & & 2.28 & 2.21 & 2.27 & 2.31 & 2.29 & 2.38 & 2.28 & 2.25 & 2.18 & 2.25 & 2.23 & 2.25 \\
\hline & $M$ & 81 & 47 & 68 & 64 & 38 & 42 & 25 & 99 & 64 & 42 & 16 & 42 \\
\hline & & .754 & .602 & .618 & .666 & .693 & .768 & 690 & .593 & .515 & .600 & .654 & 689 \\
\hline & $S$ & 93 & 28 & 99 & 92 & 82 & 25 & 34 & 74 & 93 & 94 & 98 & 03 \\
\hline & & 3.56 & 3.40 & 3.33 & 3.28 & 3.32 & 3.33 & 3.39 & 3.41 & 3.38 & 3.41 & 3.37 & 3.39 \\
\hline \multirow{3}{*}{ 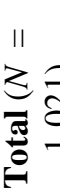 } & $M$ & 12 & 35 & 20 & 89 & 62 & 10 & 67 & 82 & 20 & 72 & 90 & 18 \\
\hline & & 1.16 & 1.10 & 1.06 & 1.05 & 1.07 & 1.07 & 1.11 & 1.11 & 1.12 & 1.10 & 1.12 & 1.10 \\
\hline & $S$ & 207 & 691 & 479 & 615 & 667 & 014 & 159 & 778 & 242 & 979 & 560 & 404 \\
\hline
\end{tabular}


Arab World English Journal (AWEJ) Volume 12. Number 2. June 2021

Saudi Female EFL Undergraduates’ Knowledge

Alghizzi

\begin{tabular}{ccccccccccccc}
\hline \multicolumn{110}{c}{ ANOVA results } \\
\hline \multirow{2}{*}{$\boldsymbol{F}$} & 197. & 175. & 137. & 108. & 129. & 114. & 140. & 149. & 155. & 150. & 139. & 155. \\
& 918 & 991 & 974 & 360 & 414 & 230 & 380 & 180 & 755 & 400 & 482 & 587 \\
\multirow{2}{*}{ Sig. } & .000 & .000 & .000 & .000 & .000 & .000 & .000 & .000 & .000 & .000 & .000 & .000 \\
& $*$ & $*$ & $*$ & $*$ & $*$ & $*$ & $*$ & $*$ & $*$ & $*$ & $*$ & $*$ \\
\hline
\end{tabular}

$1=$ Choosing a research topic, $2=$ Introduction, $3=$ Literature review, $4=$ Methodology, $5=$ Results, $6=$

Discussion, $7=$ Conclusion, $8=$ References, $9=$ Citations and quotations, $10=$ Secondary and primary resources, $11=$ Research manuals e.g., APA, $12=$ Organization of the paper

Note. $(*)$ indicates the significant results at 0.05 .Appendix $\mathbf{E}$

Table 4. Saudi Female EFL undergraduates' general perceptions of research method courses

To what extent do you agree or disagree with the following statements?

The research method course:

\begin{tabular}{|c|c|c|c|c|c|c|}
\hline \multirow{2}{*}{\multicolumn{2}{|c|}{$\begin{array}{c}\text { Academic level and } \\
\text { number }\end{array}$}} & \multicolumn{5}{|c|}{ Statements } \\
\hline & & 1 & 2 & 3 & 4 & 5 \\
\hline \multirow[b]{2}{*}{$3(N=124)$} & $M$ & 4.2500 & 3.9516 & 4.0484 & 3.9435 & 3.8952 \\
\hline & $S$ & .84223 & .91824 & .87285 & .87701 & .98623 \\
\hline \multirow[b]{2}{*}{$4(N=272)$} & $M$ & 4.1801 & 4.0515 & 4.1654 & 4.1728 & 4.0882 \\
\hline & $S$ & .82885 & .89542 & .77687 & .85666 & .86737 \\
\hline \multirow[b]{2}{*}{$5(N=248)$} & $M$ & 4.1048 & 4.0161 & 4.1290 & 4.0806 & 4.0081 \\
\hline & $S$ & .89369 & .87691 & .83901 & .88255 & .94373 \\
\hline \multirow[b]{2}{*}{$6(N=200)$} & $M$ & 4.1600 & 3.8850 & 4.0950 & 3.9700 & 3.9950 \\
\hline & $S$ & .85325 & .93065 & .90001 & .92920 & 91056 \\
\hline \multirow{2}{*}{$7(N=177)$} & $M$ & 4.1525 & 3.9944 & 4.1638 & 4.1243 & 4.1073 \\
\hline & $S$ & .90101 & .93843 & .87985 & .96902 & .99704 \\
\hline \multirow{2}{*}{$\begin{array}{c}\text { Total }(N= \\
1,021)\end{array}$} & $M$ & 4.1616 & 3.9882 & 4.1283 & 4.0744 & 4.0304 \\
\hline & $S$ & .86338 & .90849 & .84609 & .90225 & .93308 \\
\hline \multicolumn{7}{|c|}{ ANOVA results } \\
\hline \multicolumn{2}{|l|}{$\boldsymbol{F}$} & .628 & 1.086 & .562 & 2.280 & 1.323 \\
\hline \multicolumn{2}{|l|}{ Sig. } & .642 & .362 & .690 & .059 & .260 \\
\hline \multicolumn{7}{|c|}{$\begin{array}{l}1=\text { is beneficial. } \\
2=\text { is a good foundation for scientific research. } \\
3=\text { is important for understanding scientific research. } \\
4=\text { is necessary to write a scientific research proposal. } \\
5=\text { should be mandatory in any bachelor's degree program. }\end{array}$} \\
\hline
\end{tabular}

Note. (*) indicates the significant results at 0.05 .

\section{Appendix F}

Table 5. Saudi Female EFL undergraduates' perceptions of the research method course components

To what extent do you agree or disagree with the following statements?

This research method course helps me:

\begin{tabular}{ccccccccccc}
\hline $\begin{array}{l}\text { Academic } \\
\text { level and } \\
\text { number }\end{array}$ & & $\mathbf{1}$ & $\mathbf{2}$ & $\mathbf{3}$ & $\mathbf{4}$ & $\mathbf{5}$ & $\mathbf{6}$ & $\mathbf{7}$ & $\mathbf{8}$ & $\mathbf{9}$ \\
\hline & $\boldsymbol{M}$ & 4.1855 & 4.0323 & 3.8871 & 3.9677 & 3.9194 & 3.8710 & 3.9113 & 3.8952 & 3.7742 \\
$\mathbf{3}(N=$ & & & & & & & & & \\
$124)$ & $\boldsymbol{S}$ & .82014 & .89202 & .91251 & .94512 & .95931 & .97920 & .96282 & .92674 & .99461
\end{tabular}


Arab World English Journal (AWEJ) Volume 12. Number 2. June 2021

Saudi Female EFL Undergraduates’ Knowledge

Alghizzi

\begin{tabular}{|c|c|c|c|c|c|c|c|c|c|c|}
\hline \multirow{2}{*}{$\begin{array}{r}4(N= \\
272)\end{array}$} & $M$ & 4.4044 & 4.1397 & 4.1471 & 4.2022 & 4.0882 & 4.1434 & 4.1544 & 4.0956 & 4.2059 \\
\hline & $S$ & .77677 & .85626 & .85933 & .82372 & .87584 & .83159 & .89177 & .84503 & .89787 \\
\hline \multirow{2}{*}{$\begin{array}{r}5(N= \\
248)\end{array}$} & $M$ & 4.2218 & 4.0605 & 3.9798 & 3.9194 & 3.8871 & 4.0726 & 3.9597 & 3.9556 & 4.0524 \\
\hline & $S$ & .87429 & .85861 & .92404 & .90520 & .94556 & .89690 & .92556 & .87824 & .91395 \\
\hline \multirow{2}{*}{$\begin{array}{r}6(N= \\
200)\end{array}$} & $M$ & 4.2350 & 3.9700 & 3.9000 & 4.0800 & 3.8400 & 3.9750 & 3.9750 & 3.9700 & 3.9700 \\
\hline & $S$ & .82045 & .87345 & .86239 & .83492 & .92666 & .93743 & .93743 & .94529 & .92920 \\
\hline \multirow{2}{*}{$\begin{array}{c}7(N= \\
177)\end{array}$} & $M$ & 4.3559 & 4.2147 & 4.1921 & 4.2260 & 4.0452 & 4.0791 & 4.0791 & 4.1073 & 4.0904 \\
\hline & $S$ & .85472 & .85228 & .88378 & .86261 & 1.03253 & .99685 & .88193 & .87568 & .99016 \\
\hline \multirow{2}{*}{$\begin{array}{c}\text { Total }(N \\
= \\
1,021)\end{array}$} & $M$ & 4.2919 & 4.0872 & 4.0343 & 4.0852 & 3.9628 & 4.0490 & 4.0294 & 4.0147 & 4.0500 \\
\hline & $S$ & .83138 & .86616 & .89322 & .87536 & .94484 & .91905 & .91882 & .89046 & .94374 \\
\hline \multicolumn{11}{|c|}{ ANOVA results } \\
\hline \multicolumn{2}{|l|}{$F$} & 2.709 & 2.320 & 4.736 & 5.230 & 2.864 & 2.305 & 2.447 & 2.005 & 5.022 \\
\hline \multicolumn{2}{|c|}{ Sig. } & $.029 *$ & .055 & $.001 *$ & $.000 *$ & $.022 *$ & .057 & $.045^{*}$ & .092 & $.001 *$ \\
\hline $\begin{array}{l}1=\text { Und } \\
2=\text { Diff } \\
3=\text { Iden } \\
4=\text { Writ } \\
5=\text { Utili } \\
6=\text { Cons } \\
7=\text { Choc } \\
8=\text { Have } \\
9=\text { Revi }\end{array}$ & $\begin{array}{l}\text { tanc } \\
\text { entia } \\
\text { y the } \\
\text { he it } \\
\text { the } \\
\text { ler re } \\
\text { a s } \\
\text { gen } \\
\text { v do }\end{array}$ & $\begin{array}{l}\text { ow to ch } \\
\text { between } \\
\text { esearch p } \\
\text { oduction } \\
\text { rary and } \\
\text { arch ethi } \\
\text { able rese } \\
\text { al unders } \\
\text { mentatio }\end{array}$ & $\begin{array}{l}\text { se a rese } \\
\text { search ty } \\
\text { blem. } \\
\text { ith the re } \\
\text { ternet to } \\
\text { and prol } \\
\text { ch desigr } \\
\text { nding ab } \\
\text { tyles anc }\end{array}$ & $\begin{array}{l}\text { ch topic. } \\
\text { s and cla } \\
\text { arch que } \\
\text { rite the li } \\
\text { citation } \\
\text { nd instru } \\
\text { t reportin } \\
\text { eferencin }\end{array}$ & $\begin{array}{l}\text { fications. } \\
\text { ons. } \\
\text { ature revi } \\
\text { nt for dat } \\
\text { he results }\end{array}$ & $\begin{array}{l}\text { w. } \\
\text { collection } \\
\text { and writing }\end{array}$ & he discus & & & \\
\hline Note. $(*)$ & dico & $\begin{array}{l}\text { the sign } \\
\text { Table }\end{array}$ & Sauc & nale & $\begin{array}{l}\text { ppen } \\
\text { und }\end{array}$ & $\mathrm{G}$ & . & 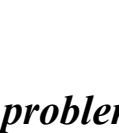 & & \\
\hline
\end{tabular}

To what extent do you agree or disagree with the following statements?

I encounter some difficulties in:

\begin{tabular}{|c|c|c|c|c|c|c|c|}
\hline \multirow{2}{*}{\multicolumn{2}{|c|}{$\begin{array}{c}\text { Academic level and } \\
\text { number }\end{array}$}} & \multicolumn{6}{|c|}{ Research problems } \\
\hline & & 1 & 2 & 3 & 4 & 5 & 6 \\
\hline $3(N=124)$ & $M$ & 3.8629 & 3.6371 & 3.6290 & 3.5726 & 3.7177 & 3.6613 \\
\hline & $S$ & 1.12137 & 1.11410 & 1.15095 & 1.08331 & 1.00858 & .98680 \\
\hline $4(N=272)$ & $\begin{array}{r}M \\
S\end{array}$ & $\begin{array}{l}3.9743 \\
1.05358\end{array}$ & $\begin{array}{l}3.8676 \\
1.00043\end{array}$ & $\begin{array}{l}3.8640 \\
1.05559\end{array}$ & $\begin{array}{l}3.9228 \\
.99330\end{array}$ & $\begin{array}{l}3.8897 \\
.97324\end{array}$ & $\begin{array}{l}3.8897 \\
.88591\end{array}$ \\
\hline $5(N=248)$ & $\begin{array}{r}M \\
S\end{array}$ & $\begin{array}{l}3.9395 \\
1.06108\end{array}$ & $\begin{array}{l}3.7984 \\
.98966\end{array}$ & $\begin{array}{l}3.8024 \\
1.03642\end{array}$ & $\begin{array}{l}3.7944 \\
1.01509\end{array}$ & $\begin{array}{l}3.8710 \\
.98135\end{array}$ & $\begin{array}{l}3.7863 \\
1.04876\end{array}$ \\
\hline $6(N=200)$ & $\begin{array}{c}M \\
S\end{array}$ & $\begin{array}{l}3.9000 \\
.99748\end{array}$ & $\begin{array}{l}3.7450 \\
.95632\end{array}$ & $\begin{array}{l}3.7850 \\
.92360\end{array}$ & $\begin{array}{l}3.7450 \\
1.03699\end{array}$ & $\begin{array}{l}3.8000 \\
.96679\end{array}$ & $\begin{array}{l}3.6950 \\
1.03796\end{array}$ \\
\hline $7(N=177)$ & $\begin{array}{c}M \\
S\end{array}$ & $\begin{array}{l}4.0113 \\
1.13312\end{array}$ & $\begin{array}{l}3.7797 \\
1.03465\end{array}$ & $\begin{array}{l}3.7514 \\
1.13082\end{array}$ & $\begin{array}{l}3.8079 \\
1.14184\end{array}$ & $\begin{array}{l}3.7684 \\
1.09103\end{array}$ & $\begin{array}{l}3.8305 \\
1.06844\end{array}$ \\
\hline $\begin{array}{c}\text { Total }(N= \\
1,021)\end{array}$ & $\begin{array}{c}M \\
S\end{array}$ & $\begin{array}{l}3.9442 \\
1.06634 \\
\end{array}$ & $\begin{array}{l}3.7835 \\
1.01032 \\
\end{array}$ & $\begin{array}{l}3.7855 \\
1.05255 \\
\end{array}$ & $\begin{array}{l}3.7943 \\
1.04825 \\
\end{array}$ & $\begin{array}{l}3.8257 \\
.99949 \\
\end{array}$ & $\begin{array}{l}3.7884 \\
1.00309 \\
\end{array}$ \\
\hline
\end{tabular}

Arab World English Journal

www.awej.org

519

ISSN: 2229-9327 
Arab World English Journal (AWEJ) Volume 12. Number 2. June 2021

Saudi Female EFL Undergraduates’ Knowledge

Alghizzi

\begin{tabular}{lcccccc}
\hline \multicolumn{7}{c}{ ANOVA results } \\
\hline $\boldsymbol{F}$ & .496 & 1.210 & 1.126 & 2.542 & .946 & 1.708 \\
Sig. & .739 & .305 & .343 & $.038^{*}$ & .436 & .146 \\
\hline
\end{tabular}

$1=$ Knowing all or some research basic components and their specific elements (research topic, abstract, acknowledgment, table of contents, tables and figures, dedication, introduction, literature review, methodology, results, discussion, conclusion, references, appendices).

$2=$ Writing all or some research basic components.

$3=$ Citing, quoting, summarizing, and paraphrasing sources.

$4=$ Allocating primary and secondary resources.

$5=$ Collecting and analyzing data.

$6=$ Using research manuals to organize the research paper.

Note. $(*)$ indicates the significant results at 0.05

\section{Appendix H}

Table 7. Female Saudi EFL undergraduates' research suggestions

To what extent do you agree or disagree with the following statements?

It would be helpful if:

\begin{tabular}{|c|c|c|c|c|c|c|}
\hline \multirow{2}{*}{\multicolumn{2}{|c|}{$\begin{array}{c}\text { Academic level and } \\
\text { number }\end{array}$}} & \multicolumn{5}{|c|}{ Research suggestion } \\
\hline & & 1 & 2 & 3 & 4 & 5 \\
\hline $3(N=124)$ & $\begin{array}{r}M \\
S\end{array}$ & $\begin{array}{l}3.9435 \\
.93966\end{array}$ & $\begin{array}{l}3.8710 \\
.86455\end{array}$ & $\begin{array}{l}3.8710 \\
.93676\end{array}$ & $\begin{array}{l}3.9435 \\
.95681\end{array}$ & $\begin{array}{c}3.8387 \\
1.01523\end{array}$ \\
\hline $4(N=272)$ & $\begin{array}{r}M \\
S\end{array}$ & $\begin{array}{r}4.1765 \\
.91629\end{array}$ & $\begin{array}{l}3.9596 \\
.86454\end{array}$ & $\begin{array}{r}3.9191 \\
.87655\end{array}$ & $\begin{array}{r}4.0441 \\
.86650\end{array}$ & $\begin{array}{l}4.0478 \\
.79755\end{array}$ \\
\hline $5(N=248)$ & $\begin{array}{r}M \\
S\end{array}$ & $\begin{array}{r}4.1694 \\
.91520\end{array}$ & $\begin{array}{l}4.0847 \\
.89809\end{array}$ & $\begin{array}{r}4.0202 \\
.91523\end{array}$ & $\begin{array}{r}4.0242 \\
.93049\end{array}$ & $\begin{array}{l}4.0282 \\
.97914\end{array}$ \\
\hline $6(N=200)$ & $\begin{array}{c}M \\
S\end{array}$ & $\begin{array}{l}4.0000 \\
.90226\end{array}$ & $\begin{array}{l}3.9400 \\
.90025\end{array}$ & $\begin{array}{c}3.9050 \\
1.02038\end{array}$ & $\begin{array}{r}3.8200 \\
.98614\end{array}$ & $\begin{array}{r}3.8700 \\
.97872\end{array}$ \\
\hline $7(N=177)$ & $\begin{array}{r}M \\
S\end{array}$ & $\begin{array}{r}4.2881 \\
.93025\end{array}$ & $\begin{array}{r}4.0904 \\
.81378\end{array}$ & $\begin{array}{l}3.8814 \\
1.01273\end{array}$ & $\begin{array}{l}4.0339 \\
1.04391\end{array}$ & $\begin{array}{l}4.0791 \\
.95612\end{array}$ \\
\hline Total $(N=1,021)$ & $\begin{array}{c}M \\
S\end{array}$ & $\begin{array}{r}4.1312 \\
.92377 \\
\end{array}$ & $\begin{array}{r}3.9980 \\
.87335 \\
\end{array}$ & $\begin{array}{l}3.9285 \\
.94650 \\
\end{array}$ & $\begin{array}{l}3.9814 \\
.95108 \\
\end{array}$ & $\begin{array}{r}3.9882 \\
.93717 \\
\end{array}$ \\
\hline \multicolumn{7}{|c|}{ ANOVA results } \\
\hline $\begin{array}{l}F \\
\text { Sig. }\end{array}$ & & $\begin{array}{l}3.877 \\
.004^{*}\end{array}$ & $\begin{array}{l}2.123 \\
.076 \\
\end{array}$ & $\begin{array}{l}.843 \\
.498 \\
\end{array}$ & $\begin{array}{l}2.054 \\
.085\end{array}$ & $\begin{array}{l}2.402 \\
.048 *\end{array}$ \\
\hline
\end{tabular}

$1=$ Each student was assigned a research supervisor other than the course teacher.

$2=$ A student could coauthor an article with their research supervisor.

$3=$ A research course was taught in all academic levels of the Bachelor of Arts.

$4=$ A research club (similar to the writing club) was established at the college.

$5=$ Research seminars or conferences for student research were held.

Note. (*) indicates the significant results at 0.05 . 